\title{
Right To The City: \\ Lagos, An Emerging Revanchist City In Nigeria?
}

\author{
Chinwe R. Nwanna (Ph.D.) \\ Associate Professor, Coordinator, Social Work Department, \\ Department of Sociology, Faculty of Social Sciences, \\ University of Lagos, Akoka, Yaba, Lagos Nigeria
}

\begin{abstract}
Right to the city is a concept that is part of discourse about contemporary urban development with its resultant social inequalities while revanchist city refers to a city that has zero tolerance policies against the poor, marginalized and downtrodden people who are seen as threats to urban order and culprits of urban decay. Gathering data from secondary sources, this chapter $x$-rayed programmes and policies executed by Lagos State between 2007 and 2015. The results showed that various processes of neoliberal restructuring of Lagos city had threatened democracy. Lagos State government, in a bid to revitalize the city, demolished some slum areas and evicted the residents because it would no longer tolerate the existence of slums in the centre of the state with a megacity plan for a 'world class' Lagos. Beggars and the destitute were forcibly removed from the streets and taken to the rehabilitation centre in Ikorodu. Some were evacuated to their various states or countries. The result further revealed that a number of the beggars were sent to Kirikiri Prison while illegal aliens were expelled and repatriated to their homelands. It was also observed that riding commercial motor-cycles popularly known as 'okada' was banned in most parts of the city. Markets in Tejuoso and Oshodi were demolished and rebuilt beyond the reach of the former traders. Also banned was street trading. With all these inhumane strategies, this article concludes that Lagos is becoming a revanchist city and suggests that the state should jettison this neoliberal legislation and reconsider liberal policies characterised by redistributive policy, affirmative action and antipoverty legislation because constitutionally in Nigeria, every individual has the freedom to live in any region, state, or city of his/her choice.
\end{abstract}

\section{INTRODUCTION}

Urbanisation in Lagos metropolitan has assumed a geometric proportion and has raised the demand for housing. Correspondingly, the provisions of urban infrastructure and housing to meet this demand has remained low, resulting in the acute shortage of housing to the teeming population of the State (Oshodi, 2012). Since the in-migrants must have shelter, all forms of informal procedures are being adopted to provide housing. This has resulted in noncompliance with physical planning regulations and development control standards. This in turn has culminated in slum development in most local government areas in Lagos State. Slums and squatter settlements in Lagos are both the products of, and vehicles for modernizing activities. . Agbola and Jinadu (1997 cited in Nwanna, 2015) reported that a 1981 World Bank assisted urban renewal project identified forty-two "blighted areas" in the Lagos metropolis alone and the State Urban Renewal Board has identified about 75 blighted areas across the state in recent years (Jimoh et al. 2013). Atere (2001 cited in Nwanna, 2015) has shown that these areas are in dire need of upgrading or regeneration.

Nigeria is a federation of thirty-six states and federal capital, Abuja. Constitutionally, every individual has the right to reside in town, city or any state of his/her choice. However, some 
states particularly Lagos, have had a paradigm shift from liberal to neoliberal policies that are against the marginalised and disadvantaged groups of people. Lagos State had planned to turn Lagos into a mega city. In this process, the state executed exclusionary urban policies which could be said to be urban revanchism.

Urban revanchism has occurred in other parts of the world e.g. New York (Smith, 1996); Glasgow (MacLeod, 2002), the cities of Quito and Guayaquil in Ecuador (Swanson, 2007), Rotterdam (Uitermark and Duyvendak, 2008; van Eijk, 2010), and Guangzhou (Huang et al., 2014). It has not been studied extensively particularly in Nigeria. Equally, Right to the city is another aspect of fundamental human rights that has not been interrogated extensively globally and in Nigeria in particular. To fill this gap therefore this chapter set out to examine programmes and policies of Lagos State government during the fourth Republic (2007 - 2015) to assess whether they were revanchist in nature or not and how they had affected the right to the city of Lagos dwellers. To achieve these objectives, extant literature is analysed.

\section{LITERATURE REVIEW}

In x-raying literature, the key concepts in the area of study, revanchist city and right to the city, are defined and illuminated and earlier studies are also reviewed.

\section{Revanchist city}

The concept 'revanchist city' is difficult to define but in order to understand it, three views will be discussed. Revanche is a French word for revenge and was introduced into urban studies by Neil Smith, an urban geographer, in the 1990s. For us to understand the meaning of a revanchist city, it is pertinent to discuss the origin of revanchism. In the late 19th century Paris, a group of bourgeois nationalist reactionaries known as revanchists repressed the liberalism of the then government of the working-classes who controlled the city for some months after the defeat of the government of Napolean III (Smith, 1996). According to Smith (1996), these revanchists vowed to reinstate the bourgeois order with a strategy that fused militarism and moralism with claims about restoring public order on the streets. They pursued the workingclasses whom they regarded as enemies with a noxious blend of hatred and viciousness, intent on exacting revenge upon all those who had 'stolen their vision of French society from them.

From this nuance, Smith (1996) coined the concept of the revanchist city to capture the disturbing urban condition created by a political shift from the liberal era of the post-1960 period characterised by redistributive policy, affirmative action and antipoverty legislation to the era of neoliberal policies typified by a discourse of revenge against minorities, the working class, feminists, environmental activists, immigrants, gays and lesbians labelled the 'public enemies' of the bourgeois political elite and their supporters. For Smith $(1996$, p. 43) urban revanchism is "revengeful and reactionary".

In analysing revanchism in New York, Smith (1998 p. 1 cited in Cook, 2014) describes it as an act of avenging those who have "stolen New York from the white middle class people that see the city as their birthright". He highlights a range of revanchist strategies in 'post-liberal' New York (between 1994-2001) as 'zero tolerance' policing within public space, associated police brutality and abuse, high levels of incarceration, termination of contracts for some providers of homeless shelters, the removal of the homeless from public space, state-sponsored gentrification, the shrinking and marketisation of welfare services for marginalised groups, and cutbacks imposed on the City University of New York.

In another perspective, Hubbard (2004 cited in Cook, 2014) extended the revanchist city thesis to include patriarchal relations in the urban landscape. Hubbard argues that punitive policing 
against sex workers in London and Paris is not only about reviving capital accumulation and gentrification under neo-liberalism but also about "the re-inscription of patriarchal relations in the urban landscape" (Hubbard, 2004 p. 666 cited in Cook, 2014). Harvey (2008) sees revanchist city as a city that has zero tolerance policies against the poor, marginalised and downtrodden people who are seen as threats to urban order and culprits of urban decay.

On the contrary, Cook (2014) argues that revanchism should be understood as a form of punishment. According to him punishment can sometimes be viewed as the opposite of revenge. While punishment is forward-looking and justified, revenge is often viewed as reactionary, excessively cruel and unjust. Although he believes that this might not be an appropriate binary because punishment can also include some traits of revenge. To understand revanchism therefore Cook (2004) defines punishment as involving an evil or an unpleasantness to the (actual or supposed) offender, conducted with special authority from the institution(s) whose laws or rules have been broken. Important within this, is that the pain or unpleasantness involved in the punishment, is for the most part intended and not merely a coincidental or accidental outcome. Cook (2014) further states that framing urban revanchism as punishment, therefore, blends two schools of reasoning for punishment: retributivism and consequentialism. Urban revanchism is retributive in the sense that it is backward-looking i.e. it is about people being punished in direct response to their past crimes and misdemeanours. Here, marginalised groups are punished for their 'crime' of taking the city. It is also consequentialist in that it is often forward-looking i.e. it punishes people for what might happen in future. Unlike most consequential thinking on punishment, which seeks to avoid future crimes and reoffending, a central goal of urban revanchism is to avoid further declines in capital accumulation and inward investment. Here the targets of urban revanchism are framed as barriers to local economic development as their presence may discourage people from visiting, living and investing in the area. This compelled the government to demolish slum areas and squatter settlements for renewal, revitailsation, gentrification or regeneration. This is because these areas are on prime locations that will yield high capital accumulation or profit if gentrified.

In view of the afore-stated, this article adopts the definitions by Harvey (2008) and Cook (2014). This implies that urban revanchism is zero tolerance and punishment to the marginalised population for their misdemeanours, crimes of taking to the city and phobia of what might happen in the future. What then is "right to the city?" The answer will be found in the next section.

\section{Right to the city}

Definition of right to the city is also problematic. The phrase, right to the city, was developed by a French sociologist and philosopher Henri Lefebvre (1968 cited in Plyushteva, 2009).

Harvey (2008) conceptualises the right to the city more as a political platform and an inspiring slogan than a legally codified practice. He avers that right to the city is far more than an individual liberty to access urban resources. According to him, right to the city is a right to change oneself by changing the city. It is a common rather than an individual right since this transformation inevitably depends upon the exercise of a collective power to reshape the processes of urbanization. He argues that the freedom to make and remake cities and oneself is one of the most precious yet most neglected aspects of human rights. Harvey maintains that the Right to the City is more than just improving people's neighbourhoods and housing, or improving the city and its surroundings. According to him, it is about democratic control over the city, with the right to access, occupy and use urban space. 
In his analysis of the right to the city, Plyushteva (2009) states that the right to the city can be used to denote an enabling right, a right-as-means rather than right-as-end for those pursuing or defending their other fundamental rights in an urban context, for those actively engaging with the architecture of citizenship, which is always 'under construction', always in need of creative tensions, always producing inequalities and injustices at one end while resolving them at another. In this perspective, for example, the auto-construction of slums on the peripheries of the city would not be regarded as claiming the right to the city, but as exercising the fundamental right to shelter. The right to the city can then be the concept used to resolve the conflict between the slum-dwellers right to shelter and the right of surrounding residents to peace, quiet and aesthetic view. The full exercising of the right to the city would inevitably produce major 'disruptions' and inconveniences.

In this article therefore, right to the city will be conceptualised as both individual and collective right to shelter, urban services and resources. To gain more insight into this phenomenon, earlier studies will be illuminated in the next section.

\section{Earlier studies}

Smith (2009) reported that in the 1990s, New York exhibited some revanchism because of the policies of Rudolph Giuliani who was elected Mayor on the promise that he would offer a better quality life for the people. He blamed the failures of earlier liberal policies on the marginalized populations. He identified homeless people, prostitutes, squatters, reckless bicyclists, unruly youth etc. as the major threats to urban order and the culprits of urban decay. MacLeod (2002 cited in Cook, 2014) suggested that dismissive treatment of the homeless people in Glasgow, Scotland in the 1990s was imprints of an emerging politics of revanchism. Uitermark and Duyvendak (2008 cited in Cook, 2014) identified another type of revanchism. They found that the policies of populist parties in Rotterdam, Netherlands, were directed to ethnic minorities and Muslims which was an attempt to discipline marginalised ethnic groups.

Furthermore, zero-tolerance policies of some countries have been described as revanchism e.g. anti-crime control by urban police force in Britain, Oslo and Bremen, Vienna and Barcelona, Stockholm and Dublin (Smith, 2009). In Spain, the language of zero tolerance was extended to kids smoking, bad behaviour in schools, public drinking etc. (Smith, 2009). Smith has also identified other forms and cases of urban revanchism e.g. evictions of tens of thousands of paupers in Shanghai and Beijing for gentrification; the non redistribution of wealth in postapartheid Johannesburg; the white race riots targeted beach-going Australian Muslims, Arabs, South and South-East Asians and other people of colour as foreigners; killing of 186 people in São Paulo, Brazil in a two week spate of violence that virtually brought the city to a halt in May 2006 etc. Smith (2009) explains that in São Paulo and Rio de Janeiro, there is a long history of police violence, much of it deployed against street and drug gangs but virtually all of it targeting the poor.

The above literature has demonstrated that revanchism, both subtle and repressive, has been studied in other countries but not in Nigeria therefore the need for this study. It is pertinent to situate this article within a theoretical framework and this is reviewed below.

\section{THEORETICAL FRAMEWORK}

This chapter is anchored on a combination of two perspectives: a) Kelling and Wilson's (1982) broken windows theory and b) political economy of urban studies by Logan and Molotch (1987). 
Broken windows theory was introduced in 1982 by Kelling and Wilson and is often mentioned in connection with zero-tolerance policing. The theory posits that low-level disorder such as vandalism, public drinking etc. must be tackled quickly or else the problems in the area will quickly escalate (Bottoms, 2012). The theory takes into consideration spatial exclusion and social division as certain people behaving in a given way are considered disruptive and therefore unwanted. By removing unwanted people from the streets, the urban politicians, businesses, and community leaders believe that the residents will feel safer and have a higher regard for those that protect them. Excluding the unruly and people of certain social statuses is an attempt to keep the balance and cohesion of a community. It is in this vein that urban managers formulate zero tolerance policies to remove the unwanted people. However, this theory has been challenged by Taylor (2001). He argues that changes in levels of physical decay, superficial social disorder, and racial composition do not lead to higher crime, rather economic decline does and that urban politicians, businesses, and community leaders should work together to improve the economic fortunes of residents. It is also criticised for lack of empirical evidence that disorder, when left unchallenged, causes crime (Bottoms, 2012).

Political economy stems from the work of Marx and Engels. It refers to the interplay between political and economic forces in a society. Emphasis is placed on the spatial use of land based on social conflict according to a Marxian model of society. Capitalist economic forces merge with political decision-making processes to determine which and how different parcels of land are used and developed. In their contribution to the political economy paradigm, Logan and Molotch (1987) view the city as a "growth machine" where real estate developers, bank officials, local politicians, corporate executives, government agencies, and chambers of commerce all share a common interest. The central thesis of their work is that market in land and buildings orders the urban phenomena and determines what city life can be. Growth machine ideology influences local governments to view cities not as places where people live, work and have social relationships, but solely as a place where it is necessary to create a good business climate (Weinstein, 2007).

These two theories are germane to explicate the policies and programmes of Lagos State between 2007 and 2015 and therefore are extrapolated. The broken windows theory explains why Lagos State had zero tolerant policies against people living on the fringe of the city, homeless, hawkers, beggars, traders, squatters, and unruly youth while the political economy thesis explicates the real estate business in Lagos State. Here in Lagos, there is a boom in land and building markets. In the light of this, the government saw slum areas, former Tejuoso and Oshodi markets as viable places for investment and therefore demolished them and built modern markets and houses beyond the economic power of the former residents and stall owners respectively. The next section of this article presents the methods used in the study.

\section{METHODOLOGY}

This is a qualitative research derived from a content analysis of secondary data such as Lagos State policies, internet documents, journal articles etc. Programmes and policies executed by Lagos State between 2007 and 2015 were x-rayed. In the next section, the study setting is described.

\section{Lagos State context}

Lagos State is located on the south western part of Nigeria with a landmass of 3,577 square kilometres representing $0.4 \%$ of the total landmass of the federation. Administratively, Lagos state is divided into 20 local government areas (LGAs) and 37 local development councils (LDCs). The metropolis comprises both the islands (Lagos Island, Victoria Island, and Ikoyi) and the mainland. Lagos is the economic hub of Nigeria, and much of the nation's economic 
wealth and activities are concentrated in the city. Until 1991, Lagos served as the federal capital of the country. Abuja is country's administrative and political capital but Lagos is still Nigeria's industrial, commercial and financial centre. Lagos is the only African city rated as one of the world's Mega Cities having a phenomenal growth in urban population from 230,256 in 1950 (Nwanna, 2004) to over 9.0 million inhabitants in 2006 (National Population Commission (NPC), 2010) although a parallel census conducted by the state produced a higher figure of 17.6 million people (Obia, 2007; Nwanna, 2011). While the State is essentially a Yorubaspeaking environment, it is a socio-cultural melting pot attracting both Nigerians and foreigners alike. There is also an admixture of other ethnic groups.

The results of the study will be presented in the section below.

\section{RESEARCH RESULTS}

\section{Lagos State's programmes and policies from 2007 to 2015}

This section is discussed under subheadings of different programmes and policies executed by the state between 2007 and 2015.

\section{Housing programmes and policies}

The research revealed that Governor Ahmed Tinubu's administration (1999-2007) inherited nearly a failed state from the military regime and adopted visionary and exemplary leadership approaches to promote development, resuscitate the state's value systems, and bring back Lagos lost glory. His major objectives were to provide affordable mass housing schemes and create the New/Satellite Town Development Scheme, reduce poverty, and reorient value systems and so on. It was also revealed that the immediate past Governor Fashola succeeded him in 2007 with the same vigour and commitment. His goal was to turn Lagos into one of the most modern mega cities of the 21st century. His initiatives included the establishment of the Lagos Metropolitan Development and Governance Project, the Lagos Island Revitalization project which aimed to "upgrade derelict residential areas" in Lagos (Abosede, 2006) and the formulation of the Medium Term Sector Strategy of the Housing Sector for Lagos for 20112013. His vision was to achieve "a Lagos State where every citizen had access to quality housing that met his/her needs". Unfortunately, most of the houses commissioned so far by Governor Fashola and his predecessor, favoured the rich. For instance, in Ifako/Ijaye "lowcost" housing estate, a flat went for about N4.5 million. No indigent person or salary earner could afford that. Their promises were, therefore, a mere propaganda and remain a mere rhetoric.

Lagos State government had also set out to gentrify slums. On February 23, 2013, the government forcibly razed houses in Badia East, a large slum neighbourhood in Lagos with a population of about 40,000 people. Workers had settled in the area more than fifty years ago upon taking jobs in the city centre (Balogun, 2013). The government said it could evict the community because the land was a Federal property. Early that fateful Saturday, a black police vehicle pulled up, armed and uniformed policemen sprang out to quell any restiveness while the houses were destroyed before the dismayed residents. The government no longer tolerated the existence of slums in the centre of a state with a megacity plan for a 'world class', middle and upper class Lagos. Lagos State had also resisted any attempts to make the state financially responsible for the costs of resettling the slum dwellers, indeed they relied on a weak legal system and the rights and powers they have under the Land Use Act to carry out this visceral gentrification. Also, slums in Mushin, Oluwole and Makoko were demolished. The residents were evicted from their homes, without plan to rehabilitate them (Rashy, 2012). They were given only 72 hours notice to leave just like in Badia East ((Rashy, 2012; Balogun, 2013). In Makoko/Iwaya, the government's quit notice described them as "environmental nuisances" 
that "undermined the megacity status" of Lagos. It stated that their menial existence was detrimental to the government's determination to beautify the Lagos waterfront. This was to justify Fashola's resounding slogan "Eko o ni baje," which means Lagos will not spoil or degenerate.

These areas are centrally situated in prime locations with colossally increasing value. The buildings erected on these slum and squatter settlement areas depress this value instead of increasing it, because they no longer belong to the changed circumstances. They were pulled down and replaced by others.

\section{Eviction programmes and policies towards street cleansing, begging, handicapped and mentally sick}

During Fashola's second inauguration into office in May 2011, he claimed that his policies and programmes were not intended to discriminate against any person(s). However, shortly after that, his administration imposed punitive strategies on the poor, the marginalised and the downtrodden. For instance, Awoyinfa and Obe (2013) reported that beggars and the destitute were forcibly removed from public places and taken to the rehabilitation centre in Ikorodu, an out sketch of Lagos. About 20 beggars were convicted by the Special Offences Court in Alausa for begging alms on the streets of Lagos. Among them was a cripple who had hernia and was brought to Lagos by a relation to raise money for the surgical operation (Awoyinfa and Obe, 2013). Some were evacuated to their various home states or countries. In February 2013, the government took this harsh strategy against the beggars to another level by charging a number of them with "constituting a nuisance in public by begging for alms" and for conducting themselves as "disorderly persons without any visible means of livelihood" (Awoyinfa and Obe, 2013). They were sent to Kirikiri and Badagry Prisons for months pending the final judgment by the judge. Furthermore, a new Immigration Department was opened in Lagos. "Illegal aliens" were expelled and shipped back to their homelands in the midnight. This was executed by the Kick Against Indiscipline (KAI) Department of the state government, several trips were undertaken, conveying beggars and the homeless to various parts of the country.

On Wednesday July 24, 2013 at about 3: 00 am, officials of Lagos State Government forcefully dumped many Nigerian citizens, mostly Igbos including petty traders, the elderly, physically and mentally challenged, men, women and children along the expressway at the Onitsha end of the Niger Bridge (Africans in America News Watch, 2013; Ihenyen, 2013). Prior to this incident, a similar incidence happened on September 18, 2012 and this involved more than hundred people (Africans In America News Watch, 2013). It was reported that Special Adviser to Lagos State Governor on Youths and Social Development, Dr. E. D. Badru, said that "The end result was to reunite them with their families". Africans In America News Watch (2013) further reported that Anambra State Governor, Peter Obi protested vehemently and even wrote a protest letter to the President of Nigeria, Goodluck Jonathan requesting him to direct the Attorney-General of the Federation to investigate these incidents. Also, human rights activists protested against the Lagos State government yet their protests yielded no results.

It is worthy to note that this eviction/ejection policy was not limited to Igbos alone. Ihenyen (2013) reported that in April 2009, the Lagos State government expelled one hundred and twenty-nine persons of Oyo state origin. They were believed to be beggars and were dumped at Molete in Ibadan. A number of Hausa/Fulani people from the northern part of the country were not left out of the forceful ejection.

The afore-stated measures did not deter people from street begging in Lagos as the problem continued unabated. This now compelled the state government to evacuate another set of 
beggars in February 2015 (Olowoopejo, 2015). However, it was gathered that twenty-two destitute rescued earlier from the streets were undergoing training at the rehabilitation centre, in Majidun, Ikorodu while five children rescued from the streets had been sent to schools after completing their rehabilitation exercise (Olowoopejo, 2015).

\section{Traffic law and programmes}

On August 2, 2012, Governor Babatunde Fashola signed into law a bill which prohibited the operations of commercial motorcyclists on 475 roads in the state (Esene, 2014). According to the traffic law, only those with 200cc engine capacity could operate in the permitted areas.

\section{Programmes and policies towards environmental sanitation, markets and street trading}

Governor Babatunde Raji Fashola regime commenced the mega-city project shortly after he assumed office in June 2007 with the radical cleaning up of Oshodi, hitherto notorious for its clutter and criminality. Next was the beautification and greening of many erstwhile dirty and dark spots all over the state and thus giving the city a great facelift. Markets in Tejuoso, Yaba and Oshodi were demolished and rebuilt beyond the pockets of the earlier poor occupants. To crown it all, petty and street trading was banned leaving the poor traders with no means of livelihood. The "Kick Against Indiscipline" (KAI) brigade seized people's goods when apprehended. Everywhere in Lagos, the poor became persona non grata.

\section{DISCUSSION OF THE RESULTS}

\section{Right to the city and an emerging revanchism in Lagos}

In the last section we were able to demonstrate some of the punitive strategies orchestrated by the past democratic dispensation. Lagos State exhibited 'zero tolerance' programmes and policies within public space, associated police brutality and abuse, high levels of incarceration of some beggars, the removal of the destitute from public space, forceful eviction of slum and squatter settlement dwellers, state-led gentrification, forceful ejection and evacuation of some residents to their home states and countries respectively, banning the operation of commercial motor cycles within some areas of the state, demolition of stalls in Oshodi and Tejuoso markets. All these translate to revanchism against the poor, destitute, marginalised, some ethnic groups, physically and mentally challenged persons as typified by Smith $(1996,1998)$; Harvey (2008); Cook (2014) and Hubbard (2004 cited in Cook, 2014)

Analysis of the programmes and policies revealed that Lagos State government, in a bid to revitalize the city, demolished some slum areas and evicted the residents because it would no longer tolerate the existence of slums in the centre of a state with a megacity plan for a 'world class' Lagos. The actions also violated the residents' right to the city as described by Harvey (2008) and Plyushteva (2009). In Nigeria, every individual has fundamental human right to life and right to live in any city within the country. Chapter IV of the 1999 Constitution of the Federal Republic of Nigeria Section 41, Sub-section (1) prescribes that "every citizen of Nigeria is entitled to move freely throughout Nigeria and to reside in any part thereof, and no citizen of Nigeria shall be expelled from Nigeria or refused entry thereby or exit therefrom. The forcible ejection of Nigerian citizens from Lagos and their forced relocation to regions of their ethnic origin touches on the constitutional right of Nigerian citizens to live or settle in any part of the country freely and without molestation. The Lagos State Government argued that it was part of preparing the Lagos metropolis as a modern mega-city able to attract tourists and genuine business interests from all over the world.

Secondly, Ihenyen (2013) argues that governments have fundamental obligations towards their citizens. Section 14(1) of the Constitution states that the Federal Republic of Nigeria shall be a state based on the principles of democracy and social justice. In subsection (2)(b) of the 
same section, it is provided that the security and welfare of the people shall be the primary purpose of government. The same Constitution and our various extant laws clearly spell out lawful steps that should be taken when citizens engage in undesirable or unlawful acts. Lagos State government had failed in its responsibility to its citizens and has threatened the spirit of democracy in the state. It is her responsibility to provide security and welfare to the beggars and ejected people. Lagos State has the obligation to protect the interests and welfare of all Nigerians resident in Lagos.

Contrary to the forcible removal of persons, demolition of houses and markets, and stringent traffic laws, section 15(3) of the Constitution provides that it shall be the duty of the State to:

(a) Provide adequate facilities for and encourage free mobility of people, goods and services throughout the Federation and (b) secure full residence rights for every citizen in all parts of the Federation. The government should have applied wisdom in perpetuating these punitive neoliberal programmes and policies.

Badia is one of the nine beneficiaries of the two hundred million US dollars World Bank funded slum upgrading under the Lagos Metropolitan Development and Governance Project (Ibekwe and Ezeamalu, 2015) and so, could have been upgraded rather than demolished. UN-Habitat has suggested that slums can be improved by providing, in situ, those facilities that are lacking or are inadequate to the residents. Massive demolitions and forced evictions are in contravention of international law and the fundamental rights guaranteed by the Nigerian Constitution

The ban of Okada on major Lagos highways has gone a long way to reinforce the elitist image projected by the Fashola government. Some aggrieved operators protested against the policy and a few people sympathetic to their cause had urged the state government to rescind its decision in view of the number that were affected. In addition, it was reported that their association, All Nigerian Autobike Commercial Owners and Workers Association (ANACOWA) sued the state government praying the court to restrain the state from stopping them to exercise their economic right and from making use of highways belonging to the federal and not the state government (Esene, 2014). On its own part, the state government claimed that the restriction was to address carnage and avoidable deaths caused by okada accidents which had reached a frightening dimension within the state metropolis. Bisiriyu and Awoyinfa (2012) reported that the Lagos State Government promised to engage genuine commercial motorcycle operators in meaningful ventures while some would be trained to acquire skills that would make them employable. The government did not provide alternative means of transportation for those who patronised them or even jobs for the riders before banning the okadas. Many people in Lagos were then compelled to walk for kilometres or stand for hours at bus-stops, waiting in readiness to struggle for the few spaces available in the few buses when they finally arrived. Some riders became jobless increasing the level of unemployment in the state.

Before the 2015 general elections, operation of okadas was observed to be gradually returning to the banned streets. The operators had threatened not to vote for All Progressives Congress (APC), the political party of the Governor. Since democracy is a game of numbers, it seemed the government relaxed the traffic law.

Governor Fashola's programmes and policies have been criticised as being anti-people and highly elitist in nature and has undermined the principles of democracy. 


\section{CONCLUSION}

Based on all these punitive and inhumane strategies against the marginalised, poor, beggars, some ethnic groups, slum and squatter dwellers in a democratic system, it can be concluded that the poor urban dwellers have been denied their rights to the city and not only that, their fundamental human rights and the principles of democracy have been grossly violated by the Lagos State government. The chapter also concludes that Lagos State government is becoming a revanchist city. It therefore recommends that the state should jettison this neoliberal legislation and reconsider liberal policies characterised by redistributive policy, affirmative action and antipoverty legislation because constitutionally in Nigeria, every individual has the freedom to live in any region, state, or city of his/her choice.

\section{References}

Abosede, B. (2006). Housing in Lagos mega city-improving livability, inclusion and governance. Paper presented at the International conference on building Nigeria's capacity to implement economic, social and cultural rights: Lessons learned, challenges and the way forward held at Abuja between $27^{\text {th }}$ and $28^{\text {th }}$ of September 2006

Africans in America News Watch (2013). How not to be a mega-city: Lagos State government reportedly secretly deports handicapped minority tribes, elderly, men, women, and children and dump them on highways in middle of the night. Africans in America News Watch Special Report. August 1, 2013. retrieved from http://www.africansinamericanewswatch.com/a/p/news/news0187.html on 9/10/15

Atkinson, R. (2006). Policy as Catharsis: The Venting of Anger Through Urbanised Revenge. available from author, rowland.atkinson@utas.edu.au

Awoyinfa, S. and Obe, E. (2013). Seized and 'repatriated' by the kick against indiscipline brigade, Punch, 06 Sep 2013 retrieved from http://www.internationalboulevard.com/in-lagos-deporting-fellow-nigerians-to-nigeria/

Balogun, A. (2013). Fashola's threat to demolish our homes is giving us sleepless nights -Lagos slum dwellers. Saturday Punch. retrieved from http://www.punchng.com/feature/super-saturday/fasholas-threat-to-demolishour-homes-is-giving-us-sleepless-nights-lagos-slum-dwellers/ on 3/10/13

Bisiriyu, R. and Awoyinfa, S. (2012). Lagos offers okada riders job opportunities. Punch. retrieved from http://www.punchng.com/business/business-economy/lagos-offers-okada-riders-job-opportunities/ on 9/10/15

Bottoms, A. (2012). Developing socio-spatial criminology, in Maguire, M., Morgan, R. and Reiner, R. (Eds.). The Oxford Handbook of Criminology (fifth edition). Oxford: Oxford University Press.

Cook, I. R. (2014). Vengeful education? Urban revanchism, sex work and the penal politics of John Schools. Imagining urban futures working paper 14. retrieved from http://research.northumbria.ac.uk/urbanfutures/wpcontent/uploads/2012/03/A-vengeful-education-John-Schools-WP.pdfon 12/6/15

Esene, I (2014). Okada riders are making a gradual return to the roads of Lagos. YNaija.com, an internet newspaper for young Nigerians, retrieved from http://ynaija.com/okada-riders-making-gradual-return-roadslagos/ on 4/10/15

Harvey, D. (2008). The right to the city. New Left Review. Vol. 53. September - October, 2008. retrieved from http://newleftreview.org/II/53/david-harvey-the-right-to-the-city on 12/6/15

Ibekwe, N. And Ezeamalu, B (2015). Anguish, sorrow, tears as Lagos descends on Badia East again, brutally evicting residents. The Premium Times Nigeri., retrieved from

http://www.premiumtimesng.com/news/headlines/190752-anguish-sorrow-tears-as-lagos-descends-on-badiaeast-again-brutally-evicting-residents.html on 10/10/15

Jimoh H.O.; Omole, F.K.; Omosulu, S.B. (2013). An examination of urban renewal exercise of Badia East of Lagos State, Nigeria. International Journal of Education and Research. Vol. 1 No. 5 May 2013.

Kelling, G. and Wilson, J. (1982). Broken Windows: The Police and Neighborhood Safety. The Atlantic Magazine. March 1982.

Lefebvre, H. (2003). The Urban Revolution, Minneapolis 2003 and Writings on Cities, Oxford: 1996.

Logan, J. R. and Molotch, H. L. (1987). Urban Fortunes: The Political Economy of Place. Berkeley: University of California Press. 
Huang, G., Xue, D. and Li, Z. (2014). From revanchism to ambivalence: the changing politics of street vending in Guangzhou. Antipode. 46 (1): 170-189.

Macleod, G. (2002). From urban entrepreneurialism to a "revanchist city" On the spatial injustices of Glasgow's renaissance. Antipode. 34 (3): 602-624.

National Population Commission (NPC) (2010). Federal Republic of Nigeria 2006 Population and Housing Census: Priority table Volume IV population distribution by age \& sex (state \& local government area). Abuja, Nigeria: NPC

Nwanna, C. R. (2004). Rural-Urban Migration and Population Problems in Nigerian Cities” in Adejugbe, M. O. A. (Ed) Industrialization, Urbanization and Development in Nigeria: 1950 -1999. Lagos: Concept Publications.

Obia, V. (2007). Census: An unusual survey. Sunday Independent. February 11, 2007: B8

Olowoopejo , O. (2015). Lagos evacuates 260 beggars in 100 days. Vanguard, retrieved from http://www.vanguardngr.com/2015/02/lagos-evacuates-260-beggars-100-days/ on 10/10/15

Oshodi, L. (2012). Formulating a social housing policy in Lagos state - The participatory approach. International Development and Urban Governance. April 27, 2012

Plyushteva, A. (2009). The Right to the City and the Struggle over Public Citizenship. The Urban Reinventors Paper Series.

Rashy, (2012). Lagos: Mega city or mega madness. NairaLand Forum. retrieved from http://www.nairaland.com/1168114/lagos-mega-city-mega-madness on 3/10/13

Smith, N. (1996). The New Urban Frontier: Gentrification and the Revanchist City. London: Routledge.

Swanson, K. (2007). Revanchist urbanism heads south: the regulation of indigenous beggars and street vendors in Ecuador. Antipode. 39 (4): 708-728.

Taylor, R. B. (2001). Breaking away from broken windows: Baltimore neighborhoods and the nationwide fight against crime, grime, fear, and decline. Retrieved from https://www.ncjrs.gov/App/Publications/abstract.aspx?ID=186793. ISBN 0813397588

Uitermark, J. and Duyvendak, J. W. (2008). Civilising the city: populism and revanchist urbanism in Rotterdam. Urban Studies. 45 (7): 1485-1503.

Van Eijk, G. (2010). Exclusionary policies are not just about the 'neoliberal city': a critique of theories of urban revanchism and the case of Rotterdam. International Journal of Urban and Regional Research. 34 (4): $820-834$.

Vanguard editorial (2013). Deportation of citizens. Vanguard, retrieved from http://www.vanguardngr.com/2013/08/deportation-of-citizens/ on 9/10/15

Weinstein, R. M. (2007). Succession and Renewal in Urban Neighborhoods: The Case of Coney Island. Sociation Today. Volume 5. Number 2. Fall 2007

\section{MY BIO DATA}

Chinwe R. Nwanna (Ph.D.) is an Associate Professor and the Coordinator of Social Work Department in the Department of Sociology, University of Lagos, Nigeria. She has been teaching Sociology of Urban Life, Urbanization and Labour Migration since 1998 and has researched and published extensively in urban management and problems in Lagos State, Nigeria in reputable national and international journals and books. Among them are "Gentrification in Nigeria: A case of two housing estates in Lagos State" (2015), "Gentrification in Lagos State: Challenges and Prospects" (2012) and "Rural-Urban Migration and Population Problems in Nigerian Cities" (2004). 